\title{
Beyond a Literature Review of Hall's Context Dimension: Scale Development, Validation \& Empirical Findings within a Norwegian Study
}

\author{
Gillian Warner-Søderholm ${ }^{1}$ \\ ${ }^{1}$ Department of Communication, Culture and Languages, Norwegian Business School BI, Norway \\ Correspondence: Gillian Warner-Søderholm, Department of Communication, Culture and Languages, Norwegian \\ Business School BI, Norway. Tel: 47-4641-0698. E-mail: Gillian.warner.soderholm@bi.no
}

Received: February 24, 2013

Accepted: March 25, 2013 Online Published: April 18, 2013

doi:10.5539/ijbm.v8n10p27

URL: http://dx.doi.org/10.5539/ijbm.v8n10p27

\begin{abstract}
This article describes this researcher's development and validation of a new attitudinal scale to measure Hall's seminal cross-cultural dimension of High-Low Context communication within a business setting. The article also presents some initial empirical findings from the authors' recent study of Context Communication Values within the Norwegian business culture to support the face validity of the scale. The instrument developed and validated in this study contains a parsimonious five-item measurement and was empirically tested with data collected from a sample of 710 Norwegian middle managers. The psychometric properties of the scale are assessed in terms of dimensionality, reliability and validity, and the results indicate that the measure constructed to assess High-Low Context in a business setting is psychometrically sound.
\end{abstract}

Keywords: high-low context, scale development, validity, empirical findings

\section{Introduction}

Over 200 articles have been published in academic journals between 1990 and today related to Hall's 'Context' and culture. Kittler et al.'s valuable article (2011) offers a systematic review of the literature related to Hall's High-Low Context model (HC-LC). They confirm that Hall's model has been a significant theoretical framework within intercultural studies during the last five decades. Nevertheless, they conclude that most previous research which utilizes High-Low Context country classifications is based on seemingly less-than-adequate empirical evidence (Kittler et al. 2011: 63). Consequently, even though an extensive set of contexting propositions based on Hall's seminal work has emerged in the literature, few of these have been empirically examined using a quantitative instrument to measure this variable. Therefore, the purpose of this present research has been to develop and validate an attitudinal scale to measure Hall's cross-cultural dimension of High-Low Context and to then offer some empirical findings of Context Communication Values within a Norwegian business setting in order to support the face validity of the scale. The instrument is grounded in a meta-analysis of the literature and of previous exploratory instruments related to High-Low Context communication patterns.

It has been claimed that intercultural communication scholarship is poised to be a powerful force in the communication field as well as within social sciences in general (Kim \& Ebesu Hubbard, 2007). Indeed, the key role of cross-cultural communication theory within international business studies has been comprehensively researched by cultural scholars (Kluckhohn \& Strodbeck, 1961; Hall, 1959; Haire et al., 1966; Rokeach, 1968; Hofstede, 1980; Denison, 1984; Schwartz, 1992; Schein, 1992; Trompenaars, 1993, Inglehart et al., 2004; House et al., 2004, Zhang \& Zhou, 2008, Snaebjornsson \& Edvardsson, 2013). Furthermore, a tradition has now been established within cross-cultural studies to quantitatively measure perceptions of societal cultural values such as Power Distance, Gender Egalitarianism, Individualism and Uncertainty Avoidance (Among others, Hofstede, 1980; Trompenaars, 1993; House et al., 2004). Surprisingly however, the application of Hall's $(1959,1976)$ dimension of Context within communication-explicitness, directness and honesty versus implicit coding of messages has been limited to mostly qualitative studies. Nevertheless, as many as two hundred and twenty four articles have been published in business and technical communication journals between 1990 and 2006 related to context and culture, clearly establishing Hall's model of HC-LC cultures as one of the dominant theoretical frameworks for interpreting intercultural communication patterns (Cardon, 2008). As only a very few of these 
have been examined with quantitative instruments (Cardon, 2008:399), this paper proposes to bridge the gap in quantitative-based intercultural studies of Context theories by developing and validating a parsimonious measurement instrument to quantitatively measure such indirect / direct communication patterns within an intercultural business framework.

\subsection{Conceptual Background}

Context is the information that surrounds an event: it is inextricably bound with the meaning of the situation. A High Context communication message is one in which most of the information is already in the person, while very little is in the coded, explicit, transmitted part of the message. A Low Context communication message is just the opposite; the mass of information is vested in the explicit code. Societal predictors of degrees of directness of speech in a society can include Power Distance, Egalitarianism, Assertiveness and also degrees of religious values where honour and respect are key elements of a culture (House et al., 2004). Hence, individuals who value harmony, hierarchical values and an indirect communication pattern are often classified as HC communicators, where the context surrounding the words plays a significant part in the communication process. On the other hand, people who value honesty, assertiveness, candidness and a direct pattern of speech tend to be defined as LC communicators. American and Japanese intercultural scholars, for example, have applied Hall's theories in qualitative research to explore and understand the bi-polar positions of these two world powers. These scholars have placed the US and Scandinavia at the LC end of the continuum whilst Japan is placed at the HC end of the scale (Hall, 1976; Condon \& Saito, 1974; Barnlund, 1975; Kume, 1986; Ishii, 1988; Miik \& Ishii, 1997; Gudykunst \& Nishida, 1998).

\subsection{High-Low Context Measures: Theoretical Linkages}

As Hall (1976) was concerned with patterns of communication, he emphasized that a group sharing the same culture is mindful of the same things and thus culture shapes the selectivity with which they see and analyze reality (Tanure, 2002: 51). Hall's life-long research into cultural perceptions began during his period of working on Native American Indian reservations before World War II and also during his army service in Europe and the Philippines during this war. Hall claims that from his work with the Hopi and Navajo he learned "firsthand about the details and complexities of one of the world's most significant problems: intercultural relations" (Hall, 1992:76). Cultures such as Eastern cultures tend to use non-verbal cues and information about a person's background to a greater extent than members of LC cultures as for instance many Western cultures. Indeed, scholars such as Weldon and Ting-Toomey link much of their cultural research of conflict management behaviour to LC-HC communication (Guirdham, 1999: 14).

Hall's seminal work continues to command interest both in undergraduate university study programmes and as a foundation for contemporary cultural studies (Hofstede, 1980; Trompenaars \& Hampden-Turner, 1998: Gesteland, 2008; Cardon, 2008). Limitations of his work however can be considered as twofold. First, his concepts are somewhat ambiguous and this ambiguity makes it difficult to apply concepts within the framework of quantitative research design and techniques. (Dahl, 2004:12). Secondly, Hall offers no specific ranking to identify where given countries are positioned along the HC-LC continuum. Thus, this lack of quantitative comparative data and limited validation of constructs makes the concept difficult to apply in academic research (Hermeking, 2006). Nevertheless, established cultural scholars such as Hofstede (1980) and the GLOBE authors (House et al., 2004) recognize Hall's landmark studies within communication in correlation to behavioral dimensions of, for example, Assertiveness, Power Distance, Individualism and Uncertainty Avoidance. Other theoretical research on Context includes studies of behaviour, intrinsic societal values, conflict management, rhetorical sensitivity, discourse and cultural adaptability (Ting-Toomey et al., 1999; Knutsen et al., 2003; Meiners \& Miller, 2004; Marti, 2005; Arasaratnam \& Doerfel, 2005; Konig et al., 2007; Adler, et al., 2007; Brinkman, 2007; Cardon, 2008; McPherson, 2009). In fact, Hall has been cited over 3,300 times in scholarly articles for his work (Cardon, 2008: 400). A limitation of studies using the contexting continuum however has been the lack of quantitative comparative data offered to empirically support the actual construct.

Hall provided numerous rich anecdotes of various cultures and indications about how he collected data through qualitative interviews and observation. His research also led him to estimate in general terms a society's position along the Context continuum. Unfortunately, he never detailed his method nor documented any data for developing his continuum, nor did he explicitly report his empirical findings. In fact Patton (2002) concludes that Hall did not use any methods for qualitative data collection that would be considered rigorous by today's standards. A number of subsequent studies have endeavored to develop quantitative measures of contexting. A study of university students in the US, Australia, Japan, and Korea (Gudykunst et al., 1996), for example applied an exploratory instrument with 78 items to measure precise versus ambiguous information, importance of 
maintaining harmony and use of understatements in communication patterns (Cardon, 2008: 403). Kim, Pan and Park (1998) also developed a 16-item survey to measure contexting. Ohashi's (2000) quantitative research on the other hand, with 20 different items, was based on the responses of 463 American and Japanese students to normative statements about society. Richardson and Smith (2007) used a 17-item modified version of Ohashi's (2000) measure within an extensive questionnaire instrument, to research preferred channels of communication between students and their professors, to explore whether Context and Power Distance impacted choice of preferred communication channels at university.

Table 1. Exploratory quantitative studies of high-low context dimension

\begin{tabular}{|c|c|c|c|c|c|}
\hline Key researchers & $\begin{array}{l}\text { Elements of context } \\
\text { studied }\end{array}$ & $\begin{array}{l}\text { Unit of } \\
\text { analysis }\end{array}$ & $\begin{array}{l}\text { No. of } \\
\text { survey } \\
\text { items }\end{array}$ & $\begin{array}{l}\text { Applied in later } \\
\text { studies }\end{array}$ & $\begin{array}{l}\text { Documented } \\
\text { reliability } \\
\text { and validity }\end{array}$ \\
\hline $\begin{array}{l}\text { Gudykunst et al., } \\
1996\end{array}$ & $\begin{array}{l}\text { Precise vs. ambiguous } \\
\text { information, importance of } \\
\text { maintaining harmony \& use } \\
\text { of understatement }\end{array}$ & Students & 80 - items & No & Yes \\
\hline $\begin{array}{l}\text { Kim, Pan and Park } \\
\text { (1998) }\end{array}$ & $\begin{array}{l}5 \text { theoretical categories of } \\
\text { contexting: } \\
\text { Social orientation } \\
\text { Responsibility } \\
\text { Confrontation } \\
\text { Communication } \\
\text { Dealing with new situations }\end{array}$ & $\begin{array}{l}\text { MBA } \\
\text { students }\end{array}$ & 16-items & No & No \\
\hline Ohashi (2000) & Social norms in society & Students & 20 -items & $\begin{array}{l}\text { In one (amended } \\
\text { items used by } \\
\text { Richardson and } \\
\text { Smith 2007) }\end{array}$ & Yes \\
\hline $\begin{array}{l}\text { Kitayama and Ishi } \\
(2002)\end{array}$ & Communication patterns & Students & $\begin{array}{l}\text { Behavioral } \\
\text { data only }\end{array}$ & No & No \\
\hline $\begin{array}{l}\text { Oguri and } \\
\text { Gudykunst (2002) }\end{array}$ & Self-constraint & Students & 78 & Yes & Yes \\
\hline $\begin{array}{l}\text { Richardson and } \\
\text { Smith (2007) }\end{array}$ & $\begin{array}{l}\text { Preferred channels of } \\
\text { written and spoken } \\
\text { communication }\end{array}$ & Students & 17-items & No & Yes \\
\hline $\begin{array}{l}\text { Warner-Søderholm } \\
\text { (2010) }\end{array}$ & $\begin{array}{l}\text { Communication pattern } \\
\text { norms }\end{array}$ & $\begin{array}{l}\text { Middle } \\
\text { managers }\end{array}$ & 4-items & $\begin{array}{l}\text { Work in } \\
\text { progress }\end{array}$ & Yes \\
\hline
\end{tabular}

Table 1 offers a literature review of previous exploratory quantitative measures developed to measure the HC-LC dimension. A summary of the present exploratory measurement is also offered in Table 1. All earlier studies have indeed made valuable contributions to the field. Nevertheless, it could be considered that none are sufficiently parsimonious to support the inclusion of the measures in data collection for multivariate analyses, where other cultural or environmental measures are also included. Furthermore, this present review of earlier research in the field yielded only limited documented reliability and validity statistics for these measures. A further limitation found in these studies was that their unit of analysis was limited to students. This present study's goal was to develop a more parsimonious Context scale building on the work of these earlier studies and using a larger sample of middle managers.

\section{Method}

\subsection{Scale Measurement and Validation}

Two general approaches to measurement development are defined by Nunnally and Bernstein (1994): the empirical approach - criterion-referenced and the theory-driven approach - construct-oriented (House et al., 2004:123). A good example of theory-driven scales is Schwartz' Values Survey (Schwartz, 1994) and Project 
GLOBE's scales (House et al., 2004). Schwartz reviewed the empirical, philosophical and religious literature from various cultures and identified several values that he believed to be universally relevant in order to develop the measurement (Smith \& Schwartz, 1997). Project GLOBE also chose the theory-driven approach. Nunnally \& Bernstein (1994) posit that this approach has an advantage in that a target construct can be specified in relation to relevant theory before items are written (House et al., 2004:121). Thus, any potential biases which could affect the scale can be specified, and so such scales can exhibit acceptable levels of face validity (House et al., 2004:123).

Five items to measure Context within a business setting were developed in this exploratory element of the study using the theory-driven approach. Their psychometric properties, reviewed later in this article were assessed in terms of dimensionality, reliability and validity. Exploratory research is necessary when little is known about a phenomenon (Churchill, 1996; Diamantopoulos \& Souchon, 1999), particularly when no reliable and valid quantitative measures of a construct exist (Patton, 1980). In-depth interviews were conducted with Norwegian business people, in Norwegian, during the initial stage of this measurement development, as a key aim of the preliminary phase was to examine the appropriateness of conceptualizing HC-LC communication patterns and practices within a business setting.

The exploratory interviews complemented existing qualitative literature in terms of generating a pool of items to be utilized in developing items for the HC-LC scale. The item pool developed during the initial stage was subsequently refined in exploratory interviews carried out in Norwegian. The exploratory scale was composed of items following the same seven-point Likert-type scale measures which Project GLOBE applies (House et al., 2004). A response of ' 7 ' indicates complete agreement with the statement made and a response of ' 1 ' indicates a complete disagreement with the statement made.

The questionnaire items, were back-to-back translated from English to Norwegian as a quality control measure as cross-cultural literature indicates that a systematic bias may occur if respondents complete a survey that is not written in their native language (Brislin, 1986). The Norwegian Questionnaire was pre-tested in a protocol approach following advice from the scale development literature (DeVellis, 1991; Hair et al., 1998; Diamantopoulos \& Souchon, 1999). Based on feedback from practitioners and academicians, redundant and ambiguous items were modified or eliminated.

The exploratory measurement scale is made up of the following five items, depicted in the appendix. Table 2 summarizes the item wording, the Likert-type scale details, along with the theoretical and empirical underpinning of each item.

Table 2. High-low context construct items and theoretical linkages

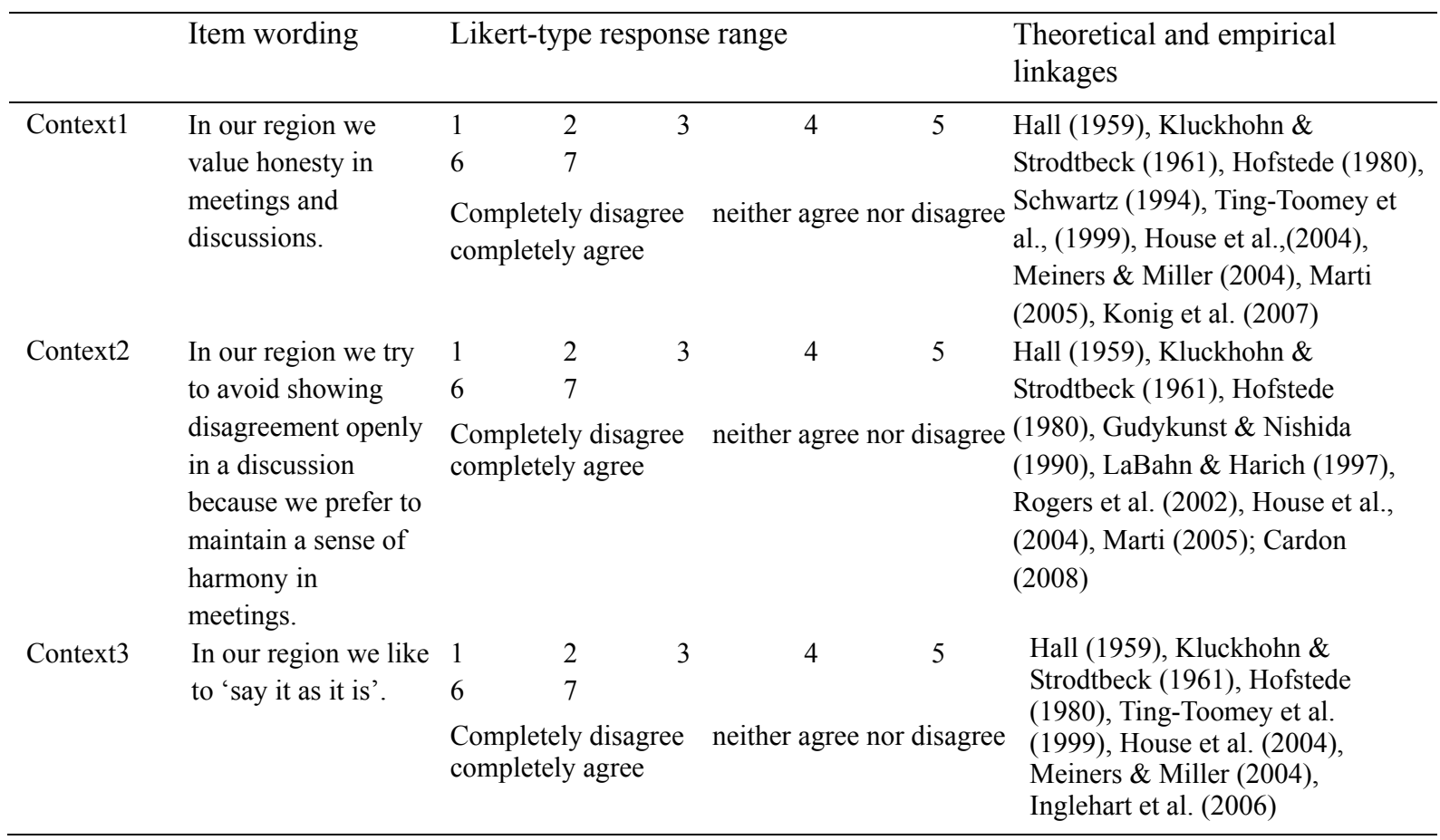




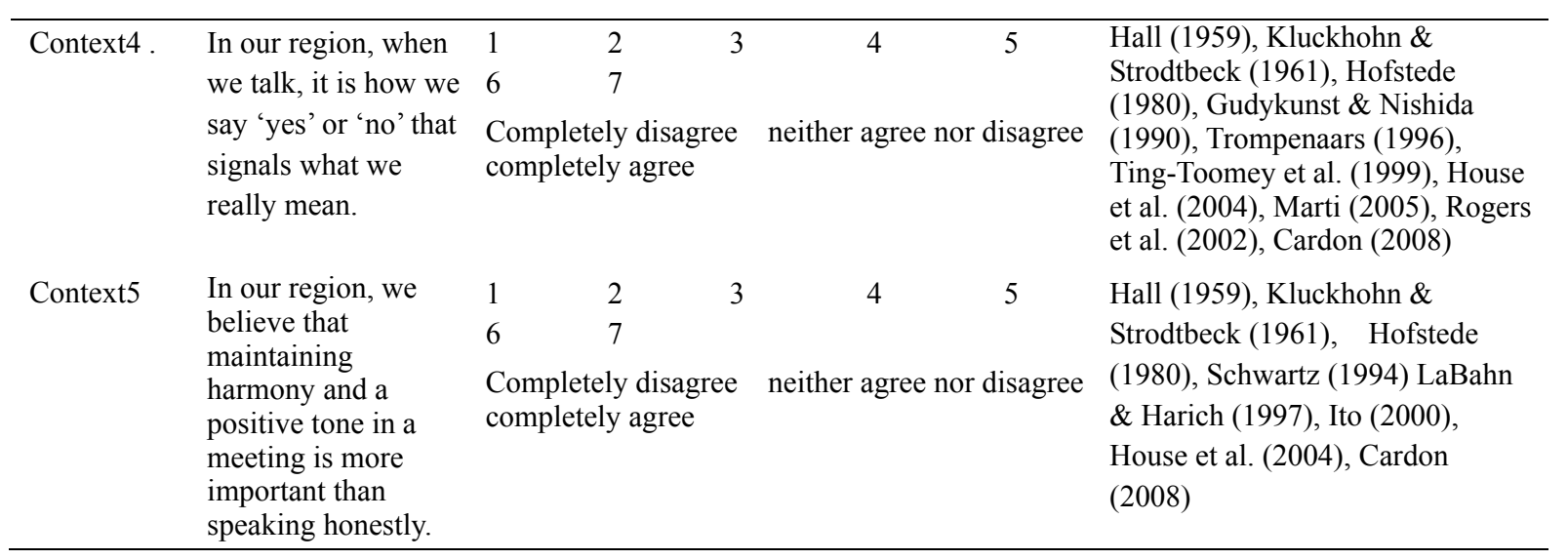

\subsection{Sample Description and Data Collection to Test Reliability and Validity of Scale Items}

The sampling method generally applied in this survey is one type of systematic stratified sampling (Bertsch, 2009). The target population from which the sample is taken can be described as a sample which is representative of the complete group of elements and objects relevant to the research project (Remenyi et al., 1998, Churchill \& Iacobucci, 2005; Holt, 2007; Hair et al., 2008). For this survey, the target population was Norwegian individuals who are in full-time employment in privately- owned Norwegian companies.

After implementing the minor amendments indicated during the pilot study (minor changes to wording and clarification of reverse-scaling procedures), the complete questionnaire of 1) Demographic questions, 2) exploratory Context measurement items and 3) items to measure project GLOBE cultural dimensions was implemented as an electronic instrument and sent respondents with a cover letter indicating the purpose, significance and confidentiality of the study. The questionnaire was sent out to over 2,000 middle managers on $9^{\text {th }}$ December 2008, with the deadline for online completion set for $23^{\text {rd }}$ December 2008. The collection period was terminated on $23^{\text {rd }}$ December with a total of 714 questionnaires received electronically. Of these 714 responses, four had significant exclusions and were deleted from the data set. A further 59 respondents completed all but one question, whilst 35 of the 710 respondents completed all but two of the questions. One respondent failed to answer three questions, nine respondents omitted to answer four questions, a further two respondents failed to answer six questions, and one respondent failed to answer 14 questions. In total, 697 responses met the criteria for completed questionnaires (97.6\% complete). These 710 responses were retained, and the missing data was treated as 'exclude cases pair-wise' in most data analyses (Plant, 2007).

One limitation of the distribution method chosen is the limited knowledge available to the researcher regarding the number of respondents who actually received the e-mail with the attached electronic survey. Consequently, it is impossible to confirm the exact response rate in terms of a percentage of the sample population. Automatic spamming programs and firewalls were seen to reject some e-mails. Furthermore, it is likely that a number of the respondents had changed jobs and e-mail addresses during the preceding two years and may consequently not have received this survey questionnaire. In addition, a number of e-mails were received in which respondents noted they were skeptical about opening an e-mail attachment due to fear of viruses. These are challenges commonly faced by researchers who collect data electronically (Warner-Søderholm, 2010).

A further element which needs to be taken into consideration in relation to the response rate is also the timing of the collection period. The collection period was December 2008 and this was during a downturn in the economy in Norway. It was in the autumn of 2008 that the Norwegian economy first noticed the effects of a global recession. Many managers at this time were pre-occupied with dealing with staff and business strategies during the start of this somewhat turbulent period in the economy. Consequently, the insecurity in both business and the job market in Norway at this time may have negatively impacted response rates. Indeed a significant problem with all global organizational level research is that managers receive many requests to participate in business surveys and research but have very little time to do so.

Clearly, non-response rate error is pervasive in research surveys (Alteren, 2007:100). Non-response is defined as observations that are not carried out because of reasons such as refusal to answer, absence and "lost" questionnaires. The greater the non-response proportion, the greater the biasing effect (Frankfort-Nachmias \& Nachmias, 1996:199). That is why, according to Hair et al. (1996), the researcher's primary concern when dealing with missing data is to determine the reason it could not be collected. In this study six hundred 
ninety-seven met the criteria for completed questionnaires, out of 714 returned surveys. Thus, missing data did not appear to be a problem in this study. In relation to non-response error, Harzing (1997) claims that cross-national mail surveys generally generate very low response rates varying between $6 \%$ and $16 \%$ (Harzing, 1997:641), whilst Bertsch (2009) posits that an average response rate of virtual surveys is mostly in the range of $15 \%$ - $29 \%$ (Bertsch, 2009:132). Apart from the manual check of data discussed above, no further non-response bias was investigated due to the anonymity of respondents and this could be seen as a limitation of such electronic surveys.

\subsection{Data Analyses to Test Reliability of the Scale}

The psychometric properties of all items were assessed using established measure development procedures (e.g. Carmines \& Zeller, 1979; Zeller \& Carmines, 1980; Devellis, 1991; Spector, 1992; Nunnally \& Bernstein, 1994). Common Factor Analysis with Promax rotation was run on all the items. The reliability of the Context instrument with five items was 0.678 . A purification of the scale, with the removal of one item (Context4) would result in an improved Cronbach's alpha of 0.734. Future researchers may wish to consider dropping Context4 in their multivariate analyses. Nevertheless, with caution, all five items were retained in this study as according to common guidelines (Devellis, 1991; Nunnally \& Bernstein, 1994; Hair et al., 1996) these are both acceptable values for an exploratory variable to be considered reliable.

Table 3. Principal components analysis: rotation method: promax with Kaiser Normalization

\begin{tabular}{|c|c|c|c|c|c|c|c|c|c|c|}
\hline \multirow{2}{*}{$\begin{array}{l}\text { Refined GLOBE \& High-Low Context societal } \\
\text { cultural practices items (Warner-Søderholm, 2010) }\end{array}$} & \multicolumn{10}{|c|}{ Structure Matrix Components } \\
\hline & 1 & 2 & 3 & 4 & 5 & 6 & 7 & 8 & 9 & 10 \\
\hline Future Orientation 1 & & & .853 & & & & & & & \\
\hline Future Orientation 2 & & & .841 & & & & & & & \\
\hline Future Orientation 3 & & & .548 & & & & & & & \\
\hline Power Distance 1 & & & & .702 & & & & & & \\
\hline Power Distance 2 & & & & .735 & & & & & & \\
\hline Power Distance 3 & & & & .751 & & & & & & \\
\hline Humane Orientation 1 & .626 & & & & & & & & & \\
\hline Humane Orientation 2 & .783 & & & & & & & & & \\
\hline Humane Orientation 3 & .627 & & & & & & & & & \\
\hline Humane Orientation 4 & .778 & & & & & & & & & \\
\hline Performance Orientation 1 & & & & & & .633 & & & & \\
\hline Performance Orientation 2 & & & & & & & & .721 & & \\
\hline Performance Orientation 3 & & & & & & & & .684 & & \\
\hline Gender Egalitarianism 1 & & & & & & & .618 & & & \\
\hline Gender Egalitarianism 2 & & & & & & & .522 & & & \\
\hline Gender Egalitarianism 3 & & & & & & & .724 & & & \\
\hline Assertiveness 1 & & & & & .752 & & & & & \\
\hline Assertiveness 2 & & & & & .830 & & & & & \\
\hline Assertiveness 3 & & & & & .448 & & & & & \\
\hline Context 1 & & .593 & & & & & & & & \\
\hline Context 2 & & .744 & & & & & & & & \\
\hline Context 3 & & .791 & & & & & & & & \\
\hline Context 5 & & .772 & & & & & & & & \\
\hline Institutional Collectivism 1 & & & & & & & & & & .438 \\
\hline Institutional Collectivism 2 & & & & & & & & & & .840 \\
\hline In-group Collectivism 1 & & & & & & .580 & & & & \\
\hline In-group Collectivism 2 & & & & & & .691 & & & & \\
\hline Uncertainty Avoidance 1 & & & & & & & & & .845 & \\
\hline Uncertainty Avoidance 2 & & & & & & .517 & & & & \\
\hline
\end{tabular}


Principal components analysis revealed the presence of ten components with eigenvalues exceeding 1 , explaining $61.72 \%$ of the variance of the dataset. Item 4 cross loaded on 2 factors: Assertiveness and Context. As discussed, in order to rationalize the scale and avoid multicollinerarity (Hair et al., 2008), the cross loaded item could be removed. The Principle Components Analysis of the dataset, with ten factor loadings applying the rotation method in the structure matrix, shows factor loadings to support the development of the complete ten cultural variables: The nine GLOBE societal practices dimensions plus the exploratory variable 'Context' (please see appendix for summary of GLOBE variables). As depicted in table 3, four of the Context items loaded strongly on the second factor $(0.600,0.742,0.792$ and 0.770 respectively), with no double loadings.

\subsection{Assessment of Construct Validity of the Context Scale Items}

Validity can be defined as the degree to which the study measures what it set out to measure (Easterby-Smith et al., 2006:134). Criticisms directed towards exploratory studies are often related to construct validity and refer to what degree a scale evaluation criterion covers 'what is the nature of the underlying variable or construct measured by this scale' (Remenyi et al., 1998:179). The findings from this exploratory study are supported in terms of concurrent validity as they correlate well qualitative data collected during the same time period (see Warner-Søderholm, 2010). Thus, there is support for the claim that this present study demonstrates how the selected measures used actually address the ideas, concepts and relationships of cultural values relating to explicit/implicit communication patterns.

\subsection{Assessment of Face Validity: Some Empirical Findings}

Qualitative studies have already shown there are regional differences in communication patterns in Norway. In terms of population traits there is an indication that significant regional differences may be found in societal cultural practices in Norway. Indeed, differing geographical, contextual and historical elements of all regions of Norway, with key factors such as differing GDP per capita, varying distance from the equator, along with significant differences in cultural variables such as Power Distance, Collectivism and Gender Egalitarianism can be seen as key predictors of variations in Context and culture (Hofstede, 1980; Grennes, 1999; Tanure, 2002; Inglehart et al., 2004; House et al., 2004, Chokar et al., 2007, Bertsch, 2009). Qualitative studies have already shown that there are regional differences in communication norms in Norway. Consequently, the quantitative findings of this study are now presented in order to assess the face validity as the findings indicate that the data collected for the study truly reflect the qualitative findings of regional differences.

A one-way between-groups analysis of variance was conducted to explore the impact of region on the cultural variable of Context within a Norwegian societal cultural communication setting. Empirical data from the subjects were divided into seven geographical regions related to where the subjects live and work in Norway (regions used by Statistics Norway in national regional research): A Levene's test for equality of variances was conducted to test whether the variances in scores are the same for all groups. Sig. value needs to be greater than .05 and the variable Context achieved .186 , showing a robust equality of means. The effect size, calculated using eta squared, size was medium for Context $($ eta $=.06)$.

Table 4. ANOVA results: mean scores for Context values per region (Examples of significant differences as 0.05 level at $\mathrm{p}<.05$ indicated with *)

\begin{tabular}{lc}
\hline 7 regions of Norway & Context \\
\hline Oslo \& Akershus region & 3.02 \\
Mid region: Hedmark \& Oppland & $3.56^{*}$ \\
South-Eastern region: Østfold, Telemark, Vestfold, Buskerud & $3.28^{*}$ \\
Southern region: Vest-Agder \& Aust-Agder & $3.38^{*}$ \\
Western region: Hordaland, Rogaland, Sogn og Fjordane, Møre og Romsdal & 2.96 \\
North \& South Trøndelag & 3.08 \\
Northern region: Finnmark, Troms \& Nordland & $2.58^{*}$ \\
\hline
\end{tabular}

Table 4 offers a summary of the ANOVA results with the mean scores for Context per region of Norway. Low scores indicate Low Context, explicit communication patterns. Higher scores indicate a High Context, more implicit, indirect communication patterns being valued to a greater extent. 


\section{Discussion of Results}

\subsection{Empirical Findings of the Study}

This quantitative data supports the proposition that there are significant differences in communication patterns in terms of traditions of communication directness / indirectness intraculturally in Norway. Face validity is supported as the scale truly reflects the regional differences only captured previously in qualitative research. The most significant findings supported by the data are the value placed upon directness of communication in the Northern region of Norway and also in the Western region. The data also indicates that a more implicit, indirect communication pattern is the norm in the Southern and mid regions and to a certain degree in the South Eastern region. In terms of initial empirical findings from the application of the measurement instrument therefore, data indicate significant intracultural differences in perceptions of Norwegian managers, for example in terms of valuing a communication pattern of 'getting straight to the point' in the Northern region. Whereas indications of a tradition of 'beating around the bush' and being less willing to speak directly is supported in mid and Southern regions in Norway.

\subsection{Scale Validation}

Assessment of content validity is a subjective process (Carmines \& Zeller, 1979; Diamantopoulos \& Souchon, 1999). Nevertheless, due to the literature and qualitative researched based nature of the scale 'Context', content validity would appear to be acceptable (Hair et al., 2008). In terms of convergent validity, correlations are found, as expected between high scores in Assertiveness and Performance Orientation (House et al., 2004), Deal-Focused behavior (Gesteland, 2010) and societies that value Achievement (Trompenaars, 2010) with low context behavior. Such relationships are also discussed in the literature. Face validity is supported by the empirical findings above and in relation to discriminate validity (Campbell \& Fiske, 1959), Exploratory Factor Analyses confirmed no high correlations with the four scale items and the GLOBE items.

The goodness-of-fit statistics of for the Context construct of CFI: 0.980 and GFI: 1.000 , were derived from the Confirmatory Factor Analysis with Structure Equation Modeling statistical analyses AMOS. Consequently, the results show that the purified measure constructed is psychometrically acceptable and therefore suitable for use in exploratory research.

\section{Conclusions}

There has been considerable debate regarding appropriate measurement of culture within intercultural communication research (Triandis, 2004). The specific aim therefore of this study has been to describe the development and validation of a new scale to better capture Hall's seminal intercultural communication concept of high-low context communication patterns. Clearly, even though studies of management and organizational behavior are typically based on statistical inference (Grennes, 2012), the field of intercultural communication has been criticized in the past for failing to produce quantitative studies which focus on actual practices of communication (Carbaugh, 2007). Hence, the purpose of this article has been threefold: 1) to develop an instrument to 'resurrect' and quantitatively measure Hall's cross cultural dimension of High-Low Context, 2) to validate this parsimonious scale, and 3) to offer some initial empirical findings from the author's recent study of HC -LC values within Norwegian societal culture, in order to support the face validity of the scale. Thus, there is support for the proposition that the aggregated items measure directness in communication patterns within a business setting. As the significance of the Context dimension has traditionally been associated with predominantly qualitative research during the last five decades, it is posited by this researcher that the development and validation of the present scale bridges a gap in the field. Future researchers are invited to use and refine this scale in comparative analyses in order to explore how communication patterns differ across cultures and how in turn these differences may impact business collaborations.

\subsection{Limitations and Recommendations for Future Research}

As with most empirical research, there are a number of limitations to the present study. The most obvious is that the present study was performed in a single country. Furthermore, the lower than expected internal reliability with the five-item measure can also been seen as a limitation. Nevertheless, as noted by Triandis (2004), when discussing issues of reliability and validity 'cross-cultural research is tricky' (Triandis, 2004:1). Indeed, Hofstede even claims that internal reliability measures such as Cronbach's alpha reliability coefficients across individuals are actually irrelevant (Hofstede, 2001:498). Consequently, he does not report these statistics. Other intercultural studies also lack conformity in terms of whether such statistical analyses are applicable societal cultural studies or not. In fact the data analyses in a number of such studies also resulted in low Cronbach's Alphas or non-reported statistics (Trompenaars \& Hampden-Turner, 1998; Grennes, 1999; Hofstede, 2001; House et al., 
2004; Bertsch, 2009)

In conclusion, overall, the quantitative based survey results discussed in this study suggest that there is evidence to support the validation of the scale developed to measure Context communication in a business setting. Moreover, propositions for intracultural differences in relation to perceptions of HC-LC differences in Norwegian societal practices are also supported. On a large scale, multi-societal empirical country comparison should be the next step in validating this measurement instrument. Indeed, as noted recently by Kittler et al. (2011:79) 'As communication across cultural borders is a phenomenon of high practical relevance, a more sophisticated empirical approach to Hall's Context idea will revive interest in Hall's important context concept among scholars'. Hence, it is hoped that this study provides a parsimonious measurement instrument to revive interest in such a relevant phenomenon as High-Low Context communication patterns. It is hoped that the development of this more parsimonious scale will motivate and facilitate further theory development and empirical investigation - so that we can at last move beyond literature reviews of Hall's seminal work in the field of cultural studies. We can then 'resurrect' Hall's seminal construct of 'Context' within a quantitative environment.

\section{References}

Adler, N. J., \& Jelinik, M. (1986). Is 'organizational culture' culture bound? Human Resource Management, 25, 73-90. http://dx.doi.org/10.1002/hrm.3930250106

Adler, N. J., Rosenfeld, L. B., \& Proctor, R. F. (2007). Interplay the process of interpersonal communication. New York: Oxford University Press.

Alteren, G. (2007). Does cultural sensitivity matter to maintaining business relationships in the export markets? An empirical investigation in the Norwegian seafood industry. Series of dissertations 4/2007, Norwegian School of Management BI.

Arasaratnam, L. A., \& Doerfel, M. L. (2005). Intercultural communications competence: identifying key components from multi-cultural perspectives. International Journal of Intercultural Communications, 29, 137-163. http://dx.doi.org/10.1016/j.ijintrel.2004.04.001

Barnlund, D. C. (1975). Public and private self in Japan and United States: styles of two cultures. Tokyo: Simul Press.

Bertsch, A. (2009). Exploring perceptions of values in US managers: interstate cross-cultural differences and similarities within the USA. DBA thesis: Reading University.

Black, S., \& Porter, W. (1991). Management behaviours and job performance: a successful manager in Los Angeles may not succeed in Hong Kong. Journal of International Business Studies, 22(1), 99-113. http://dx.doi.org/10.1057/palgrave.jibs.8490294

Brinkman, D., \& Wink, M. (2007). How to assess the intercultural competence of students? Paper for Sietar Europa Congress, Sofia.

Brislin, R. W. (1986). The wording and translation of research instruments. In W. J. Lohner \& Berry J.W. (Eds.), Field methods in cross-cultural research (pp. 137-164). Beverly Hills, CA: Sage.

Brown, P., \& Levinson, S. C. (1987). Sociolinguistic models of politeness: some universals In language usage. New York: Cambridge University Press.

Campbell, D. T., \& Fiske, D. W. (1959). Convergent and dicriminant validation by the multitrait - multimethod matrix. Psychological Bulletin, 56(2), 81-105. http://dx.doi.org/10.1037/h0046016

Carbaugh, D. (2007). Cultural discourse analysis: communication practices and intercultural encounters. Journal of Intercultural Communication Research, 3(3), 167-182. http://dx.doi.org/10.1080/17475750701737090

Cardon, P. W. (2008). A critique of Hall's contexting model. Journal of Business and Technical Communication, 22(4), 399-428. http://dx.doi.org/10.1177/1050651908320361

Carmines, E. G., \& Zeller, R. A. (1979). Reliability and validity assessment. London: Sage publications.

Chhokar, J. S., Brodbeck, F. C., \& House, R. J. (2007). Culture and leadership across the world: The GLOBE book of in-depth studies of 25 societies. New York: Lawrence Erlbaum Associates.

Churchill, G. A. (1996). Marketing research: methodological foundations. Fort Worth, Texas: Dryden Press International Edition.

Churchill, G. A., \& Iacobucci, I. (2005). Marketing research: methodological foundations. New York: South 
Western, Dryden.

Condon, J., \& Saito, M. (Eds.). (1974). International encounters with Japan: communication, contact and conflict. Tokyo: Simal Press.

Dahl, S. (2004). Intercultural Research: The Current State of Knowledge. Middlesex University Discussion Paper No. 26. Retrieved on 12th January 2004 from http://ssrn.com/abstract=658202

Denison, D. R. (1984). Bringing Corporate Culture to the Bottom Line. Organizational Dynamics, 13, 5-22. http://dx.doi.org/10.1016/0090-2616(84)90015-9

DeVellis, R. F. (1991). Scale development: theory and application. London: Sage.

Diamantopoulos, A., \& Souchon, A. (1999). Measuring Export Information Use: Scale development and validation. Journal of Business Research, 46, 1-14. http://dx.doi.org/10.1016/S0148-2963(98)00099-X

Easterby-Smith, M., Thorpe, R., \& Lowe, A. (2006). Management Research: An Introduction. Thousand Oaks, California: Sage Publications.

Ekuma, K. J. (2012) The importance of predictive and Face validity in employee selection and ways of maximizing them: An assessment of three selection methods. International Journal of $B \&$ \&., 7(22), http//doi:10.5539/ijbm.v7n22p115

Frankfort-Nachmias, C., \& Nachmias, D. (1996). Research methods in the social sciences. New York: St. Martins.

Gerhart, B. (2008). Cross cultural management research: assumptions, evidence, and suggested directions. $\begin{array}{lllll}\text { International Journal of Cross Cultural Management, } & 8, & \text { 259-74. }\end{array}$ http://dx.doi.org/10.1177/1470595808096669

Gesteland, R. (2005). Cross-Cultural Business Behavior. Copenhagen: Copenhagen University Press.

Grennes, T. (2012). Hofstede revisited: is making the ecological fallacy when using Hofstede's instrument on individual behaviour really unavoidable? International Journal of Business and Management, 7(7), 75-84. http://dx.doi.org/10.5539/ijbm.v7n7p75

Grenness, T. (1999). Perceptions of Values and Commitment of Norwegian Managers. DBA Thesis: Reading University.

Gudykunst, W. B., \& Nishada, T. (1986). Attributional confidence in low-and high context cultures. Human Communication Research, 12, 525-549. http://dx.doi.org/10.1111/j.1468-2958.1986.tb00090.x

Gudykunst, W. B., \& Nishada, T. (1998). Anxiety, unconscious and perceived effectiveness of communication across relationships and cultures. International Journal of Intercultural Relations, 25, 55-75. http://dx.doi.org/10.1016/S0147-1767(00)00042-0

Gudykunst, W. B., Matsumoto, Y., Ting-Toomey, S., Nishada, T., Kim, K., \& Heyman, S. (1996). The influence of cultural individualism-collectivism, self-construals and individual values on communication styles across $\begin{array}{llll}\text { cultures. Human } \quad \text { Communication } & \text { Research, }\end{array}$ http://dx.doi.org/10.1111/j.1468-2958.1996.tb00377.x

Guirdham, M. (1999). Communicating across cultures. London: Macmillan Press Ltd.

Hair, J. F., Black, W. C., Babin, B. J., Anderson, R. E., \& Tatham, R. L. (2008). Multivariate Data Analysis (7th ed.). Upper Saddle River, NJ: Pearson Prentice Hall.

Hair, J. F., Black, W. C., Babin, B. J., Anderson, R. E., \& Tatham, R. L. (1996). Multivariate Data Analysis (2nd ed.). Upper Saddle River, NJ: Pearson Prentice Hall.

Haire, G., Ghiselli, E. E., \& Porter, L. W. (1966). Managerial Thinking: an International Study. New York: John Wiley.

Hall, E. T. (1959). The Silent Language. New York: Doubleday.

Hall, E. T. (1976). Beyond Culture. New York: Doubleday.

Hall, E. T. (1992). An Anthropology of Everyday Life. New York: Doubleday / Anchor Books.

Harzing, A. W. (1997). Response rates in international mail surveys: results of a 22-country study. International Business Review, 641-665. http://dx.doi.org/10.1016/S0969-5931(97)00040-1

Hermeking, M. (2006). Culture and internet consumption: contributions from cross cultural marketing and 
advertising research. Journal of Computer Mediated Communication, 11, 192-216. http://dx.doi.org/10.1111/j.1083-6101.2006.tb00310.x

Herskovits, M. (1973). Cultural relativism. New York: Random House.

Hofstede, G. (1980). Culture's Consequences: International differences in work related values. Beverly Hills: CA.

Hofstede, G. (2001). Culture's Consequences:Comparing Values, Behaviours, Institutions and Organisations Across Nations. Thousand Oaks, CA: Sage.

Holt, G. (2007). Organizational culture and performance: A survey in Norway and Pakistan. DBA thesis, Reading University.

House, R. J., Javidan, M., Dorfman, P., \& Gupta, V. (2004). Culture, Leadership and Organisations: The Globe Study of 62 Societies. Thousand Oaks, CA: Sage.

Inglehart et al. (2006). World Values Survey Publications. Retrieved from http://margaux.gradvinum.se/SebTest/vvs/index_publications

Inglehart, R., Basanez, M., Diez-Medrano, J., Halman, L., \& Luijkx, R. (Eds). (2004). Human beliefs and values: a cross-cultural sourcebook based on the 1999-2002 values survey. Mexico: D.F. Siglo xx1 editors, SA Dec de C.V.

Ishii, S. (1988). Non-verbal communication in Japan, Tokyo. The Japanese studies centre: orientation seminars on Japan.

Kim, D., Pan, Y., \& Park, H. S. (1998). High- versus low-context culture: a comparison of Chinese, Korean \& $\begin{array}{lllll}\text { American } & \text { cultures. Psychology and }\end{array}$ http://dx.doi.org/10.1002/(SICI)1520-6793(199809)15:6<507::AID-MAR2>3.0.CO;2-A

Kim, M. S., \& Ebesu Hubbard, A. S. (2007). Communication in the global village: how to understand "the other". Journal of Intercultural Communication Research, 36(3), 223-235. http://dx.doi.org/10.1080/17475750701737165

Kitayama, S., \& Ishi, K. (2002). Word and voice: spontaneous attention to emotional utterances in two languages. Cognition and Emotion, 16, 29-59. http://dx.doi.org/10.1080/0269993943000121

Kittler, M. G., Rygl, D., \& Mackinnon, A. (2011). Beyond culture or beyond control? Reviewing the use of Hall's high/low context concept. International Journal of Cross Cultural Management, 11, 63-82. http://dx.doi.org/10.1177/1470595811398797

Kluckhohn, F., \& Strodtbeck, F. (1961). Variations in Value Orientations. Evanston, IL: Row, Peterson.

Knutsen, T., Komolsevin, R., Datthugawat, P., Smith, U., \& Kaweewong, B. (2003). A scale to measure Thai rhetorical sensitivity. International Journal of intercultural relations, Feb., 63-78.

Konig, C., Steinmtz, H., Frese, M., Rauch, A., \& Wang, Z. (2007). Scenario-based scales measuring cultural orientations of business owners. J. EVOL ECON., 7, 211-239. http://dx.doi.org/10.1007/s00/91-006-0047-Z

Kume, T. (1986). Perception of time of Japanese and Americans in intercultural settings. Kobe city University Journal, 37(1-3), 63-85.

LaBahn, D., \& Harich, K. (1997). Sensitivity to national business culture: effects on US Mexican channel relationship performance. Journal of International Marketing, 5, 29-51.

Marti, L. (2005). Indirectness and politeness in Turkish-German bilingual and Turkish monolingual requests. Journal of Pragmatics, 38(11), 1836-1869. http://dx.doi.org/10.1016/j.pragma.2005.05.009

McPherson, B. (2009). Learning styles among international and American Business students. Journal of International Business and Cultural Studies, 1. Retrieved from http://www.aabri.com/manuscripts/0928/.pdf

Meiners, E. B., \& Miller, V. D. (2004). The effect of formality and relational tone on supervisor/subordinate negotiation episodes. Retrieved from http://www.questia.com/googlescholar.qst.docId=000759855J

Miike, Y., \& Ishii, S. (1997). An analysis of the English Language: literature on Japanese nonverbal communication 1966-1997. Intercultural Communication Studies, 10, 119-135.

Miles, M. B., \& Huberman, A. M. (1994). An expanded source book: qualitative data analysis. Beverly Hills, CA: Sage Publications.

Modell, J. S. (1983). Ruth Benedict: Patterns of a life. Philadelphia: University of Pennsylvania Press. 
Nunnally, J. C., \& Bernstein, I. H. (1994). Psychometric theory (3rd ed.). New York: McGraw-Hill Book Company.

Oguri, M., \& Gudykunst, W. B. (2002). The influence of self construals and communication styles on sojourners' psychological and sociocultural adjustment. International Journal of Intercultural Relations, 26, 577-93. http://dx.doi.org/10.1016/S0147-1767(02)00034-2

Ohashi, R. (2000). High/low context communication: Conceptualization and scale development. Dissertation Abstracts International, 61(5), 1680. University Microfilms No. 9971973.

Pallant, J. (2007). SPSS survival manual (3rd ed.). New York: McGraw Hill.

Parsons, T., \& Shils, E. (1952). Toward a general theory of action. Evanston, IL: Row, Peterson.

Patton, M. Q. (1980). Qualitative Evaluation methods. Beverly Hills, CA: Sage Publications.

Patton, M. Q. (2002). Qualitative research and evaluation methods. Thousand Oaks: Sage Publications.

Podsakoff, P. M., MacKenzie, S. B., Lee, J. Y., \& Podsakoff, N. P. (2003). Common method biases in behavioural research. A critical review of literature and recommended remedies. Journal of Applied Psychology, 88, 879-903. http://dx.doi.org/10.1037/0021-9010.88.5.879

Remenyi, D., Williams, B., Money, A., \& Swartz, E. (1998). Doing research in business and management - an introduction to process and method. London: Sage publications.

Richardson, R. M., \& Smith, S. W. (2007). The influence of high/low context culture and power distance on choice of communication media: students' media choice to communicate with professors in Japan and America. International Journal of Intercultural Communications. http://dx.doi.org/10.1016/j.ijintrel.2007.01.002

Riise, J. H. (2005). An explanation of the relationship between organisational learning and organizational identity. DBA thesis, Henley Management College, Henley-on-Thames, Brunel University.

Rogers, E., Hart, W., \& Yoshitaka, M. (2002). Edward T. Hall and the history of intercultural communication: the United States and Japan. Keio Communication Review, 24, 3-26.

Rokeach, M. (1968). Beliefs, Attitudes and Values: A Theory of Organisation and Change. San Francisco: Jossey-Bass.

Schein, E. (1992). Organisational culture and leadership (2nd ed.) San Francisco: Jossey-Bass.

Schwartz, S. H. (1992). Universals in the Content and Structure of Values: Theoretical Advances and Empirical Tests in 20 Countries. In M. P. Zana (Ed.), Advances in Experimental Social Psychology, 25, 1-65. New York: Academic Press. http://dx.doi.org/10.1016/S0065-2601(08)60281-6

Schwartz, S. H. (1994). Cultural dimensions of values: towards an understanding of national differences. In U. Kim, H. C., Triandis, C., Kagitcibasi, S. C., Choi and G. Yoon (Eds.), Individualism and Collectivism: Theoretical and Methodological Issues (pp. 85-119). Thousand Oaks, CA: Sage.

Smith, P. B., \& Schwartz, S. H. (1997). Values. In J. W. Berry, M. H. Segal \& C. Kagitibasi (Eds.), handbook of cross-cultural psychology (vol. 3, pp.77-118). MA: Allyn and Bacon.

Snaebjornsson, I. M., \& Edvardsson, I. R. (2013). Gender, Nationality and leadershipstyle: a literature review. IJBM, 8(1).

Spector, P. E., Cooper, C. L., \& Sparks, K. (2001a). An international study of the psychometric properties of the Hofstede values survey model 1994: a comparison of individual and country/ province level results. Applied psychology: an International Review, 50(2), 269-281. http://dx.doi.org/10.1111/1464-0597.00058

Stevens, J. (1996). Applied multivariate statistics for the social sciences. Hillsdale, NJ: Lawrence Erlbaum Associates.

Tabachnick, B. G., \& Fidel, L. S. (2001). Using multivariate statistics. New York: Harper Collins.

Tanure, B. (2002). Perceptions of Values of Brazilian Managers: Cross Cultural Differences and Similarities in Brazil. DBA Dissertation: Henley PowerGen Library.

Ting-Toomey, S. (1999). Communicating across cultures. New York: The Guildford Press.

Triandis, H. C. (2004). The contingency model in cross cultural perspective. In Chemers, M. M., \& Ayman, R. (Eds.), Leadership theory and research perspectives and directions. San Diego: Academic Press. 
Trompenaars F., \& Hampden-Turner, C. (1998). Riding the waves of culture. New York: McGraw Hill.

Trompenaars, F. (1993). Riding the Waves of Culture: Understanding Diversity in Global Business. Chicago, IL: Irwin.

Warner-Søderholm, G. (2010). Understanding perceptions of cultural and intracultural societal practices and values of Norwegian Managers. DBA thesis: Reading University.

Zeller, R. A., \& Carmines, E. G. (1980). Measurement in the social sciences. London: Cambridge University Press.

\section{Appendix}

Appendix 1. Exploratory Context Scale (Warner-Søderholm, 2010)

Table 5. Exploratory context scale items

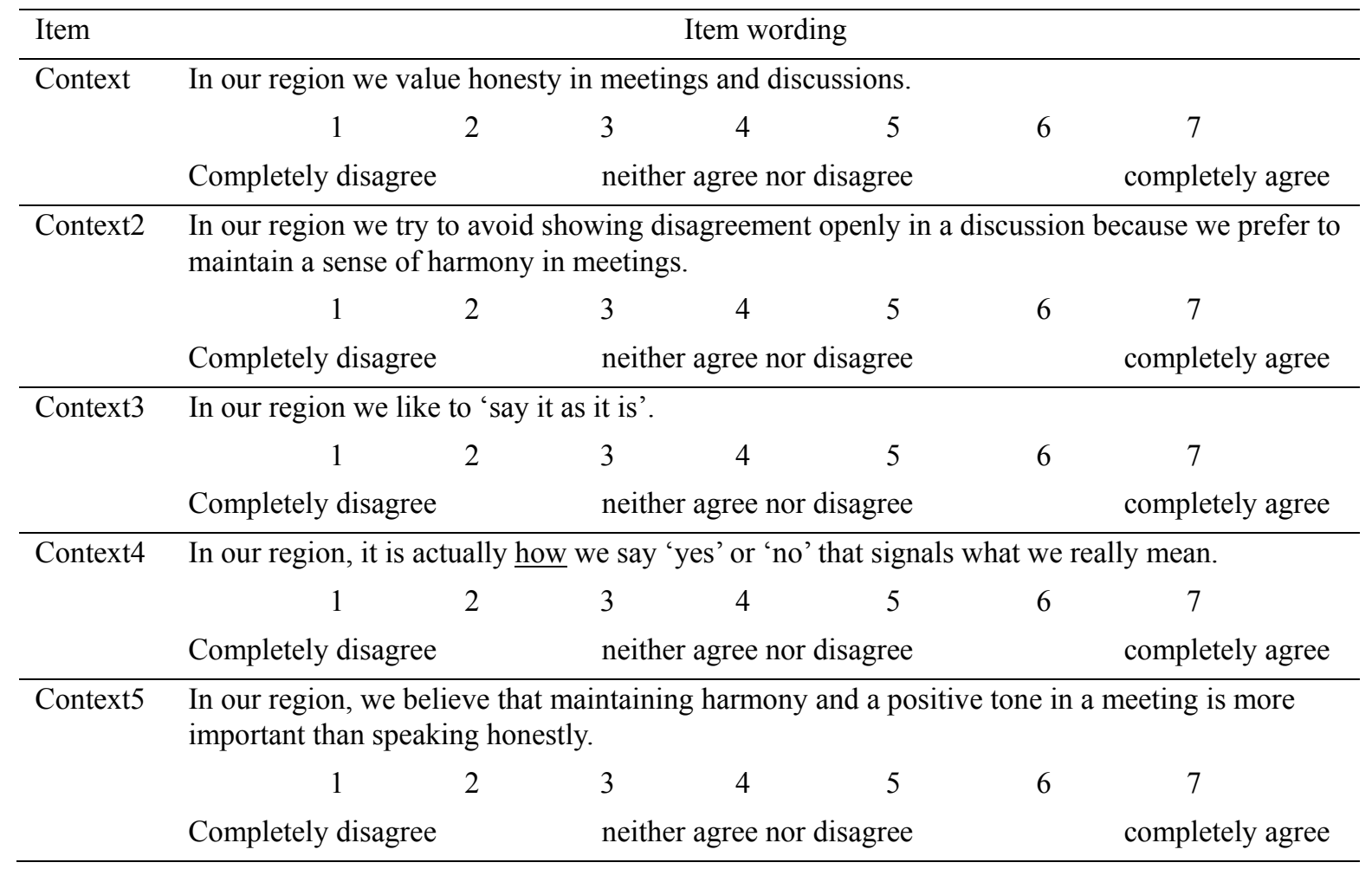

Appendix 2. SPSS Syntax for Context Measurement

The following SPSS syntax statements indicate items that need to be reverse coded in the data: Recode: Context1, Context3 $(1=7)(2=6)(3=5)(4=4)(5=3 \quad(6=2)(7=1)$ and the final syntax for creating the Societal Cultural Practices (as is) scales for Context is as follows: Context $=$ mean (Context1+ Context2+Context3+ Con5)/4 
Appendix 3. Project GLOBE (House et al., 2004)

Table 6. Overview of GLOBE societal cultural variables (House et al., 2004)

\begin{tabular}{llc}
\hline Description & Continuum & Source \\
\hline Performance Orientation (PO) & $\begin{array}{l}\text { Higher scores result in more societal value toward } \\
\text { performance }\end{array}$ & $\begin{array}{c}\text { House, et al., } \\
2004\end{array}$ \\
Humane Orientation (HO) & Higher scores result in higher humane value system & $\begin{array}{c}\text { House, et al., } \\
2004\end{array}$ \\
Gender Egalitarianism (Gen) & $\begin{array}{l}\text { Higher scores indicate higher value toward } \\
\text { egalitarianism }\end{array}$ & $\begin{array}{c}\text { House, et al., } \\
2004\end{array}$ \\
Assertiveness (Agg) & $\begin{array}{l}\text { Higher scores indicate more aggressive societal value } \\
\text { system }\end{array}$ & $\begin{array}{c}\text { House, et al., } \\
2004\end{array}$ \\
Future Orientation (FO) & $\begin{array}{l}\text { Higher scores indicate more emphasis on future } \\
\text { orientation }\end{array}$ & $\begin{array}{c}\text { House, et al., } \\
2004\end{array}$ \\
In Group Collectivism (Coll) & $\begin{array}{l}\text { Higher scores indicate a higher level of in-group } \\
\text { orientated value system }\end{array}$ & $\begin{array}{c}\text { House, et al., } \\
2004\end{array}$ \\
Power Distance Index (PDI) & Higher scores indicate more value on power distance & House, et al., \\
2004
\end{tabular}

This on-going research is a multi-phase, multi-method project examining the interrelationships between societal culture, organizational culture and leadership. A total of 170 social scientists and management scholars from 62 cultures representing all major regions of the world are engaged in this long-term programmatic series of inter-cultural studies and data has been collected from over 17,300 respondents. Table 7 is a summary of the nine GLOBE societal cultural variables applied in this data collection. 